\title{
Spatio-temporal Analysis of Demographic Characteristics: A Case Study of Samastipur District, India
}

\author{
Akhilesh Kumar Mishra*, Prabuddh Kumar Mishra\# \\ *Department of Geography, Delhi School of Economics, University of Delhi, India \\ "Department of Geography, Shivaji College, University of Delhi, India \\ prab19@gmail.com
}

Abstract: Demographic properties are an imperative concern which impedes management and development planning of a region. Present research delves into all demographic process reflecting the various states of spatial manifestation of discrete aspects of population and uneven spatial distribution in study area associated with physical, ecological and socio-economic variables. This study is examined in the context of Pusa block, Samastipur district, Bihar. This paper advocates the population dynamics with respect to allocation of resources. The study is grounded on data collected at village level from Primary Census Abstract, Directorate of Census operation, Census of India for the period of 1991 to 2011. Geographic knowledge and statistical method have been applied to portray and dictate the population growth pattern harmonizing with the spatial extent of study area.

Keywords: Demography, Population projection, Distribution and Density of Population, Ecological conditions of Villages.

\section{INTRODUCTION}

Demographic structure explicitly included 'composition of population' and changes therein' which is quite manifest significant factors for sustainable development of a region. The future prospect of population has been propagated by Simon (1977), contrary to this population growth poses negative effect on the living standards in the short run reason being. Disproportionate population growth is detrimental to natural resources and human well-being, counting human capital in context to health and education. At present, the world population is about 7.5 billion and is projected to upsurge 9.8 billion by 2050, with the current growth rate of 1.09 percent per year (Population Reference Bureau, 2017). The disproportionate population growth is not limited to environmental degradation such as losses of biodiversity and soil depletion. Malthus argued that, population growth ripostes to wage that compare negatively with the population size (Lee 2011).

Population growth and their distribution are two key concerns in any population studies (Rubenstein, 2010, p. 28). The geographical study of population growth of an area is of vital significance for understanding its dynamism as well as for planning at the local and regional levels. In 2011, the population of Pusa block extended to 132932 persons with the decadal growth of 20.37 per cent during 2001-2011 (Census of India, 2011). The growth of population is very high compared to the national average (17.64\%). Distribution and density are two separate but intimately related concepts, wherein distribution discusses the ways people get located in their spatial spread, i.e., Linear, dispersed, nucleated etc. Density, alternatively, is concerned with the ratio between the size of the population and the area (Clark, 1965). The density of population of the study area accounts for 10 persons per hectare, which is also higher than the national density. The present study pursues to analyse trend of growth and spatial distribution of population in Pusa block (District-Samastipur, Bihar) for the period of 1991 to 2011.

www.arjonline.org 


\section{Spatio-temporal Analysis of Demographic Characteristics: A Case Study of Samastipur District, India}

Few questions appropriate to demography concerning the trend of population growth, outline of the distribution, vagaries in village level population, population pattern in groups of male, female and infant needs to be answered. These problems have been deliberated in this paper.

The present study is based on two-fold objectives: (A) To have a comprehensive demographic study in context to population growth among different groups of population, and (B) To study the spatial and temporal variations in distribution and density of population in an ecological conditions of the study area for the year 1991 to 2011.

\section{Material AND Methods}

The data for the study has been utilised from Census of India. The study area is one of the Twenty blocks of district-Samastipur, situated in the great north Indian plain (Budhi Gandak plain of middle Bihar) stretching from $25^{\circ} 52^{\prime} 41^{\prime \prime} \mathrm{N}$ to $26^{\circ} 0^{\prime} 18^{\prime \prime} \mathrm{N}$ and $85^{\circ} 37^{\prime} 29^{\prime \prime} \mathrm{E}$ to $85^{\circ} 43^{\prime} 49^{\prime \prime} \mathrm{E}$ (Fig. 1) and known for its backwardness and flood vulnerability. The Block consists of 37 Villages with an area of 7590.63 hectares. The area comprises 132932 persons (2011) of which male populations share 52.40 per cent. In 2011, the average density of population was 20.51 persons per hectare (Census of India, 2011).

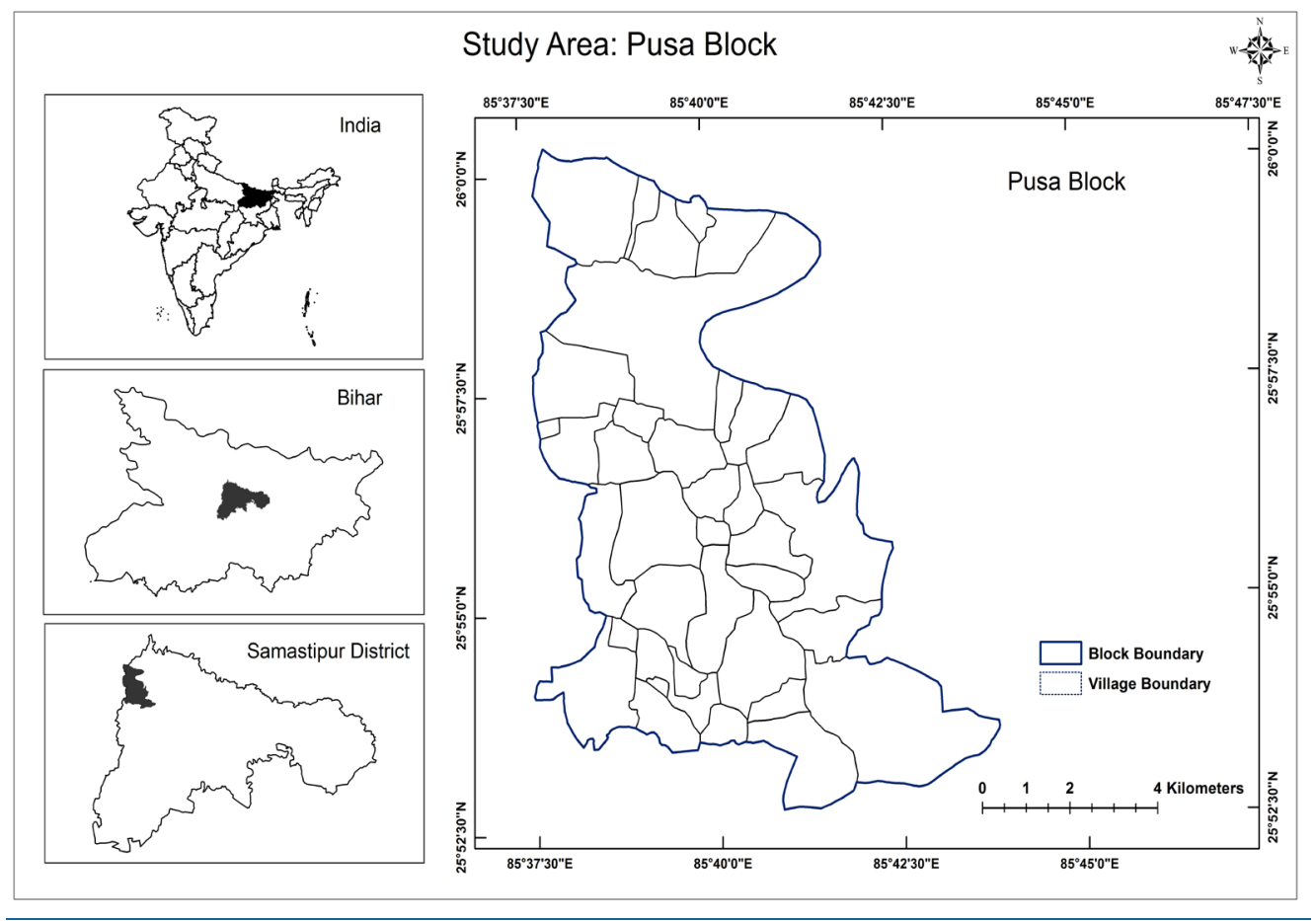

Fig1. Location Map Showing Pusa Block in India

\section{RESULTS AND DiscuSSION}

\section{Population Growth}

Any alteration of populace in a specified period of time is devoted to as population growth (Barclay, 1958; Bogue, 1969). Any reform in the scale of population over a period of an area have a great influence on socio-economic status and environment of the specified regions sparkling the number of human souls of certain time (Chip, 1984). The growth of population typically calculated in absolute number and in percentage change in numbers of population. The absolute change is the difference between two figures of population (P2-P1) at two consecutive points of time. The growth in percentage number is computed by the formula: (P2-P1) /P1*100, where P2 and P1 exhibit the 
population of an area of two consecutive points of time. The growth of population, whether positive or negative is controlled by the relative balance of fertility, mortality and migration which are generally influenced by six groups of factors: biological, environmental, economic, social, political and technological (Sauvy, 1969). Present Demographic study is performed in context of growth analysis, has been done for the two decades (19912011).

\section{Growth of Total Population}

In 2001, with a decadal growth rate of 16.24 per cent, there was a population growth of 110429 persons. On the contrary, in 2011 decadal growth rate of 20.37 per cent augmented the population by 132932 persons. The growth rate of total population during1991 to 2011 was 39.93 per cent (Census of India 1991, 2001 and 2011). Figure-2 reflects augmentation of population during 1991 to 2001, with most compelling state of growth rate in four villages ( $48.13 \%$ of total) registered more than 40 per cent growth of their total population, major of which were Gopalpur (175.82 \%), Pusa Mahamadpur Deopar (79.36 \%), Madhopur Khairi (57.11\%) etc. Nine villages $(27.13 \%$ of total) recorded 20 to 40 per cent growth in their total population, while fifteen villages ( $24.73 \%$ of total) grew with less than twenty per cent. Due to some adverse factor, nine villages recorded negative growth during 1991-2001 conceivably built ecological conditions.

The tier of total population growth of the study area during 2001 to 2011 fluctuates when considered to its previous decade (Fig.2). During this period the total population of the area bred at a rate of 20.37 per cent. 7 villages ( $69.72 \%$ of total) protracted their total population with the rate of more than 40 per cent. 15 villages ( $21.91 \%$ of total) registered 20 to 40 per cent growth in their total population, which was 9 in number during the previous decade, while the villages having less than 20 per cent imitated positive growth only ten in number (8.37\% of total) during 2001-2011 than fifteen in the previous decade. The number of villages having deleterious growth in their total population during 2001 to 2011 is slighter from nine in number in their previous figure.

The trend of total population growth in the study area dictates that the villages tend to grow faster with passing of time and improvement in the other socio-economic structures. One of the major factors behind the increasing growth rate in total population of the area can be enumerated as the decrease in the frequency of inundation vulnerability.

\section{Male - Female differentials in population growth}

The period of 1991-2011 ascertained to be beguiling enough with the growth rate of female population remaining higher than the males throughout (Census of India 1991; 2001; 2011).During this period the female population thrived rapidly with the rate of 37.66 per cent and male (42.06\%), while the total population upstretched with the rate of 39.93 per cent. The decadal disparity in male-female population growth is also trivial in the study area. During 1991 to 2001 male population growth rate was 16.58 per cent, which increased to 21.85 per cent during 2001 to 2011 with the difference of 5.27 per cent in the decadal growth rate. In contrast the female population growth rate during the period of 1991 to 2001 was 15.88 percent, while it increased to 18.78 per cent during 2001 to 2011, with a variance of 2.9 per cent in the decadal female population growth rate. Thus, the census data reflects a fact that the male population grew more rapidly in the study area during the period from 1991 to 2011 than that of the female. It is perhaps the poverty and backwardness in rural villages and socio-economic factors prevail to gender differential in ecological and culture inherits in that part of Bihar.

The study area divulges that inter and intra-gender population diverges owing to space and time thus procasting to be rutted. Although, there is an extensive spatial variation within intra-gender population growth, but such variation is very low in case of inter gender. During 1991 to 2001, four villages documented significant growth with the rate of more than 40 per cent in terms of both male and female population. Such villages having growth 
Spatio-temporal Analysis of Demographic Characteristics: A Case Study of Samastipur District, India

rate of more than 40 per cent in their male and female populace augmented in number to 7 and 8, respectively, by the period of 2001 to 2011. Thus, about 3 and 4 villages shifted to high population growth in terms of their female and male population, respectively. Eight villages recorded their male as well as female population growth in the rate between 20 to 40 per cent during 1991-2001, This figure changed in 15 and 12 villages respectively for male and female population growth (with the rate of 20 to $40 \%$ ) by the period of 2001 to 2011. It caused due to overall impact of cultural inheritance in general and the poverty in particular. Census data reflects a certain fall in the villages having a low population growth (less than 20 but positive) during the decade of 2001 to 2011 than that of 1991 to 2001 in term of their male and female population. Seven and four villages recorded low respectively in male and female population growth during 2001 to 2011, while, it was 16 in number (for male) and 18 (for female) during 1991 to 2001. Due to the division of the block in 1991 and some other factors, there is a slight increase in the number of villages having a negative male-female growth during 2001 to 2011 (Table-1).

Category wise range of population growth, 1991-2011

\begin{tabular}{|c|c|c|c|c|c|c|c|c|}
\hline \multirow[t]{2}{*}{$\begin{array}{l}\text { Range of } \\
\text { Population } \\
\text { Growth (\%) }\end{array}$} & \multicolumn{4}{|c|}{$\begin{array}{l}\text { Number of Villages and their growth rate } \\
\qquad(1991-2001)\end{array}$} & \multicolumn{4}{|c|}{$\begin{array}{l}\text { Number of Villages and their growth rate } \\
\qquad(2001-2011)\end{array}$} \\
\hline & Total & Male & Female & SC & Total & Male & Female & SC \\
\hline$>40$ & $4(88.60)$ & $4(89.74)$ & $4(87.73)$ & $6(50.79)$ & 7 (174.63) & $8(162.93)$ & 7 (168.98) & $5(682.23)$ \\
\hline $20-40$ & $9(22.19)$ & 8 (23.68) & $8(23.50)$ & $12(25.24)$ & $15(25.61)$ & $15(25.84)$ & $12(25.52)$ & $17(28.22)$ \\
\hline$<20$ & $15(12.14)$ & $16(12.21)$ & $\begin{array}{c}18 \\
(10.98) \\
\end{array}$ & 14 (13.47) & $10(14.66)$ & $9(15.24)$ & $14(13.82)$ & $10(11.17)$ \\
\hline Negative & $9(-15.85)$ & $9(-16.36)$ & $7(-20.15)$ & $5(-23.13)$ & $5(-22.16)$ & $5(-23.39)$ & $4(-27.74)$ & $5(-14.11)$ \\
\hline Total & 37 & 37 & 37 & 37 & 37 & 37 & 37 & 37 \\
\hline
\end{tabular}

Source: Census Data, 1991, 2001 and 2011.

Note: Figures in parentheses show the percentage to total villages

Infant (0 to 6 Age) Population Growth

The year of 2011 envisioned 16.76 percent of Pusa belonged to the infant group (0-6) (Census of India, 2011). In 1991, the total population of infant group (0-6 age) were 19271 (17.45\% of total population). In 2011 it increased to 22280 persons ( $16.76 \%$ of total) with the growth rate of 15.61 per cent, It is clear from the census data $(1991 ; 2001 ; 2011)$ that, although the growth rate of $0-6$ age population is increasing with time, their share in total population of the area tends to be increasing. It merely does reflect a fact that the population is growing due to health facilities as well as improving a little bit economic and ecological conditions in rural villages with agricultural activities and NRHM schemes to some extent.

The period of 1991-2011 accredited most villages with a population growth of more than 40 percent. Eight villages (69.40\% of total) protracted their total population with the rate of more than 40 per cent. 8 villages (18.43\% of total) registered 20 to 40 per cent growth in their total population. While the villages having less than 20 per cent imitated positive growth only thirteen in number (12.16\% of total) during 2091-2011. 
Spatio-temporal Analysis of Demographic Characteristics: A Case Study of Samastipur District, India

There are eight villages who recorded negative growth of 17.04 per cent during this period. However, it is very remarkable that the average growth rate of male population among 0-6 population is greater than their female counterpart during the decade of 2001 to 2011 (Census of India, 1991, 2001 and 2011).

\section{Scheduled Cast and Scheduled Tribe Population Growth}

Population of the scheduled tribes in the study region is very trivial (only $0.054 \%$ in 2011) while, about 21.67 per cent population fits in the category of Scheduled caste population in the block. The segment of SC population augmented considerably during the decade of 2001 to 2011 (39.72\%). In 1991, the total SC population of the area was 19127 persons which increased to 23368 persons (21.16\% of total population) in 2001 with the growth rate of 22.17 per cent and further 28813 persons ( $21.67 \%$ of total population) in 2011 with the decadal growth rate of 23.30 per cent. Thus, there is a triggering acceleration in the SC population, which came during 1991 to 2011, which in addition also helped in increasing the ratio of SC population into the total population of the block. Here, it is a matter of extensive concern for the planners and administrators including local governance that, the above increasing nature of 'have not' group of people need more attention and comprehensive care for rural development in present as well as future perspective.

Four villages in 2001 had more than 40 per cent of their population in SC category. They were, Sekhopur (97.64 \%); Madhopur Khairi (53.36\%); Gaura Kalyanpur (44.58\%); Naraenpur (41.71\%). This figure is little bit different in 2011 where six villages fall in such category of SC composition with some new villages or some change in the composition of earlier villages. Such villages in 2011 are Sekhopur (92.23\%); Naraenpur (74.27\%); Gaura Kalyanpur (45.14\%); Bishunpur Birauli (44.72\%); Pusa Deopur (43.09\%); Bhairo patti (40.25\%). In contrast, 15 villages (13.18\% of the total) constitute between 20 to 40 per cent of their population in SC category in 2011 (Census of India, 2011) out of which four villages have a negligible (Less than $5 \%$ ) SC population. Therefore, it is vibrant from the above fact that the concentration of SC population is ample in the area. This in addition led into the even spatial-temporal distribution of SC population growth in the block. During 1991 to 2011, 9 villages (33.34\% of the total) recorded more than 60 per cent growth in terms of their SC population. Pusa Mahamadpur Deopar (1425\%); Pusa Deopur (578.70\%); Gopalpur (368.75\%); Chak Abdullah, urf Milki (206.25\%) etc. are the most prominent among SC population growing villages. There are the thirteen villages' accounted 40 to 60 per cent growth in their SC population during this period and eight villages during 1991-2011 who recorded between 20 to 40 percent, out of which four villages accounted among less than 20 percent growth, Birauli Khurd (20 \%); Naraenpur Khairi (5.45 \%); Bishunpur Dimangra (No Growth); Repura (No Growth). Remaining three villages of the area recorded negative growth ranging between14.29 to 23.71 (Madhopur Khairi; Nawa Chak and Mahamadpur Deopar).

\section{Population Growth: A Comparative Overview}

It is imperative to study a comparative trend of population growth among different fragments of the population, i.e., total population; male population; female population; 0-6 age and SC-ST population. Such proportional analysis is also important in term of their periodic variation. Here, comparative analysis of population growth has been done in the following way based on the census data (Table-2). 
Spatio-temporal Analysis of Demographic Characteristics: A Case Study of Samastipur District, India

Table 2. Comparative growth of population (In percent)

\begin{tabular}{|l|l|l|l|l|l|l|}
\hline & \multicolumn{2}{|l|}{ 1991-2001 } & \multicolumn{2}{l|}{ 2001-2011 } & \multicolumn{2}{l|}{ 1991-2011 } \\
\hline Growth & Total Pop. & SC & Total Pop. & SC & Total Pop. & SC \\
\hline Total & 16.24 & 22.17 & 20.37 & 23.30 & 39.93 & 50.64 \\
\hline Male & 16.58 & 23.57 & 21.85 & 23.82 & 42.06 & 53.01 \\
\hline Female & 15.88 & 20.71 & 18.78 & 22.74 & 37.66 & 48.15 \\
\hline
\end{tabular}

Source: Calculated by authors based on Census data, 1991, 2001 and 2011.

During 1991-2001

The total population of the area augmented at a rate of 16.24 per cent of which male population grew more rapidly (16.58 \%) than their female counterpart (15.88 \%) throughout 1991-2001.Growth of infant population (0-6 age) diverges pointedly against the total population. This variation is quite remarkable in case of the female infant. The variation between the infant, male and the total male population growth during the period was only of 0.76 per cent. In case of SC population, the growth rate of total SC population was 22.17 per cent which were approximate six per cent more rapid than the total population growth during this period. Here one thing is to be noticed that the growth rate of SC male population was comparatively higher in case of total female and total male $(15.88 \%$ and $16.58 \%$, respectively) and their SC female counterpart as well.

During 2001-2011

The period of 2001-2011 witnessed an increase in the total population at a rate of 20.37 per cent, which was 4.13 per cent quicker than that of 1991-2001. Once again the data shows (Table-2) that the male population growth dominates over female population as it was during 1991-2001. Here, the rate of male population growth $(21.85 \%)$ dominates 3.07 per cent over that of the female population (18.78\%).The growth rate of both the male and female population increased significantly during this period than that of 1991-2001.

Through the period (1991-2011), infant population (0-6 age) nurtured at a rate of 15.61 percent, which is about five per cent faster than that of 1991 to 2001. But the matter of apprehension is that, Thus, the variation between the growth of total population and 0-6 age population tends to be increased, which in addition reflect the decreasing nature of birth rate and impact of family welfare programme to some extent in the study area. SC population augmented more rapidly (23.30 \%) during this period than it was during the period of 1991-2001 $(22.17 \%)$. It is even more interesting to know that the growth rate of SC population during this period seemed to be analogous to the previous SC population growth rate $(22.17 \%)$, which was higher than total population growth (20.37\%) during 2001-2011. One another harmoniously occurrence of this period is that the male population growth of both the 0-6 age and SC population dominates over their female counterpart. 


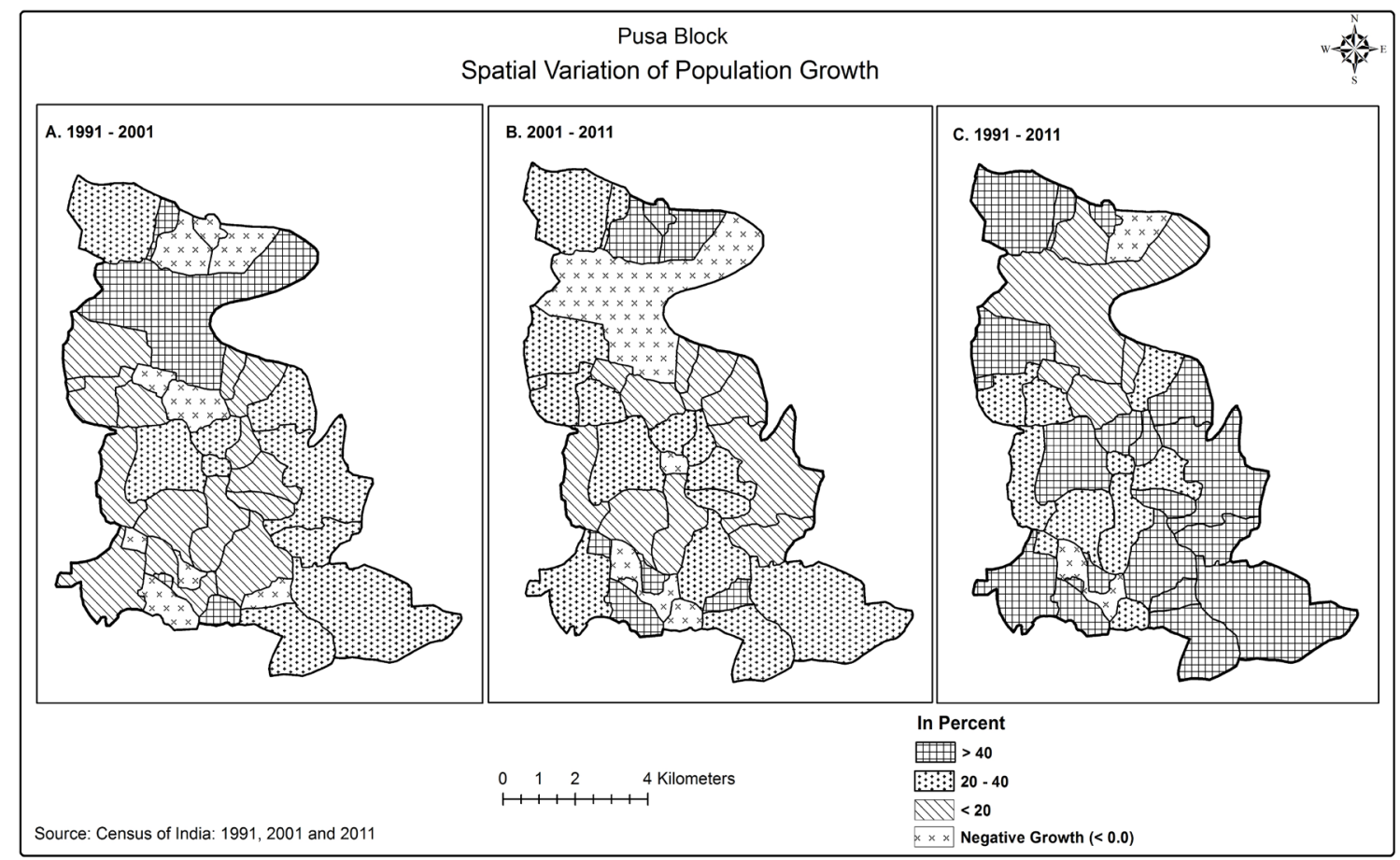

Fig2. Population growth variability pattern for three Census decades

\section{Population Projection}

The technique of presuming the future population where précised assumptions are made about the future dynamism in population, clinging to the roots of fertility, mortality and migration is termed as population change. The conventions take due regard of the past trends and make allowances for possible demographic attentions that could affect the population growth and its structure. But any calculation of future population is, by nature, hypothetical and speculative. Despite, population projection is very useful for planning of any area. There are various formulae to estimate the total amount of growth of population for a given period. A simple formula has been used here for population projection of the study area. Similar formula has been used by several authors in their works to compute population projection (Tiwari, 2011 etc.). It assumes that the population propagates similarly as an amount grows at the rate of compound interest. It is calculated as follows:

$$
\begin{aligned}
\mathrm{P}^{\mathrm{p}}=\mathrm{P}\left(\frac{1+\mathrm{R}}{100}\right)^{\mathrm{n}} \quad \text { Where, } & \mathrm{P}^{\mathrm{p}}=\text { Projected population } \\
\mathrm{P} & =\text { Present population } \\
\mathrm{R} & =\text { Annual growth rate } \\
\mathrm{n} & =\text { No. of years between } \mathrm{P}^{\mathrm{p}} \text { and }
\end{aligned}
$$

The population of Pusa block is constantly increasing. Because of amended health care services and awareness the mortality rate has declined sharply, but fertility has not shown such a trend. The population of the block in 2011 was 215643 persons and the annual rate of growth during the period 2001-2011 was 1.01 per cent (Fig 3 ). If this rate endures in future the projected population figure based on the above mentioned formula for the study area comes to be as follows (Table-3). 
Spatio-temporal Analysis of Demographic Characteristics: A Case Study of Samastipur District, India

Table 3. Population Projection (2021-2041)

\begin{tabular}{|c|c|c|c|c|c|}
\hline Village Name & 2001 & 2011 & 2021 & 2031 & 2041 \\
\hline Sri Rampur Ajodhya & 3418 & 4036 & 4828 & 5864 & 7250 \\
\hline PusaMahamadpurDeopar & 302 & 3006 & 1798520 & $1.2275 \mathrm{E}+24$ & $2.69 \mathrm{E}+192$ \\
\hline MahamadpurDeopar & 2524 & 4146 & 7729 & 17705 & 59609 \\
\hline MadapurChhapra & 2642 & 3385 & 4467 & 6118 & 8797 \\
\hline HarpurMohamda & 6028 & 7487 & 9510 & 12415 & 16774 \\
\hline PusaDeopur & 1192 & 1701 & 2584 & 4287 & 8113 \\
\hline HarpurPusa & 13871 & 11285 & 9349 & 7864 & 6700 \\
\hline Dhobgawan & 3845 & 4873 & 6344 & 8542 & 12008 \\
\hline Sekhopur & 509 & 618 & 764 & 965 & 1250 \\
\hline Malikorh & 1975 & 2408 & 2991 & 3800 & 4962 \\
\hline NawaChak & 1188 & 1386 & 1635 & 1954 & 2370 \\
\hline Jagdishpur & 1472 & 1888 & 2495 & 3423 & 4933 \\
\hline BishunpurBirauli & 348 & 360 & 373 & 386 & 400 \\
\hline BirauliKhurd & 1620 & 1830 & 2082 & 2386 & 2759 \\
\hline MahamadpurBirauli & 1830 & 2107 & 2449 & 2876 & 3419 \\
\hline Dighra & 2376 & 2678 & 3039 & 3473 & 4004 \\
\hline BishunpurBathua & 5011 & 5726 & 6598 & 7673 & 9021 \\
\hline DharmagalpurBathua & 3677 & 4512 & 5648 & 7242 & 9567 \\
\hline Bhairopatti & 322 & 318 & 314 & 310 & 306 \\
\hline Chak Abdullah, urfMilki & 482 & 710 & 1127 & 1995 & 4188 \\
\hline Kubauli Ram & 4106 & 5725 & 8428 & 13369 & 23632 \\
\hline Khaira & 1463 & 2306 & 4038 & 8331 & 22879 \\
\hline Naraenpur & 422 & 241 & 155 & 108 & 80 \\
\hline Chandauli & 9854 & 12038 & 14989 & 19095 & 25021 \\
\hline KajiaBishunpur & 3082 & 3515 & 4041 & 4689 & 5496 \\
\hline MahamadpurKuori & 7948 & 9895 & 12604 & 16514 & 22412 \\
\hline GauraKalyanpur & 1292 & 1668 & 2222 & 3081 & 4503 \\
\hline PatepurGopinath & 1363 & 1676 & 2103 & 2705 & 3587 \\
\hline Morsand & 7959 & 9520 & 11561 & 14293 & 18053 \\
\hline BishunpurDimangra & 641 & 548 & 473 & 413 & 363 \\
\hline Repura & 581 & 862 & 1382 & 2484 & 5349 \\
\hline
\end{tabular}

American Research Journal of Humanities and Social Sciences

Page 8 
Spatio-temporal Analysis of Demographic Characteristics: A Case Study of Samastipur District, India

\begin{tabular}{|l|r|r|r|r|r|}
\hline ChaklaWaini & 6683 & 8055 & 9870 & 12334 & 15783 \\
\hline Gopalpur & 1871 & 2421 & 3235 & 4502 & 6611 \\
\hline Thahra & 2493 & 3060 & 3832 & 4915 & 6496 \\
\hline BhagwanpurWainiurfGangapur & & 5373 & 6533 & 8090 & 10237 \\
\hline MadhopurKhairi & 4487 & & & & \\
\hline NaraenpurKhairi & 536 & 894 & 1707 & 4073 & 14928 \\
\hline
\end{tabular}

Source. Calculated by the authors, 2014 (Present population 2011)

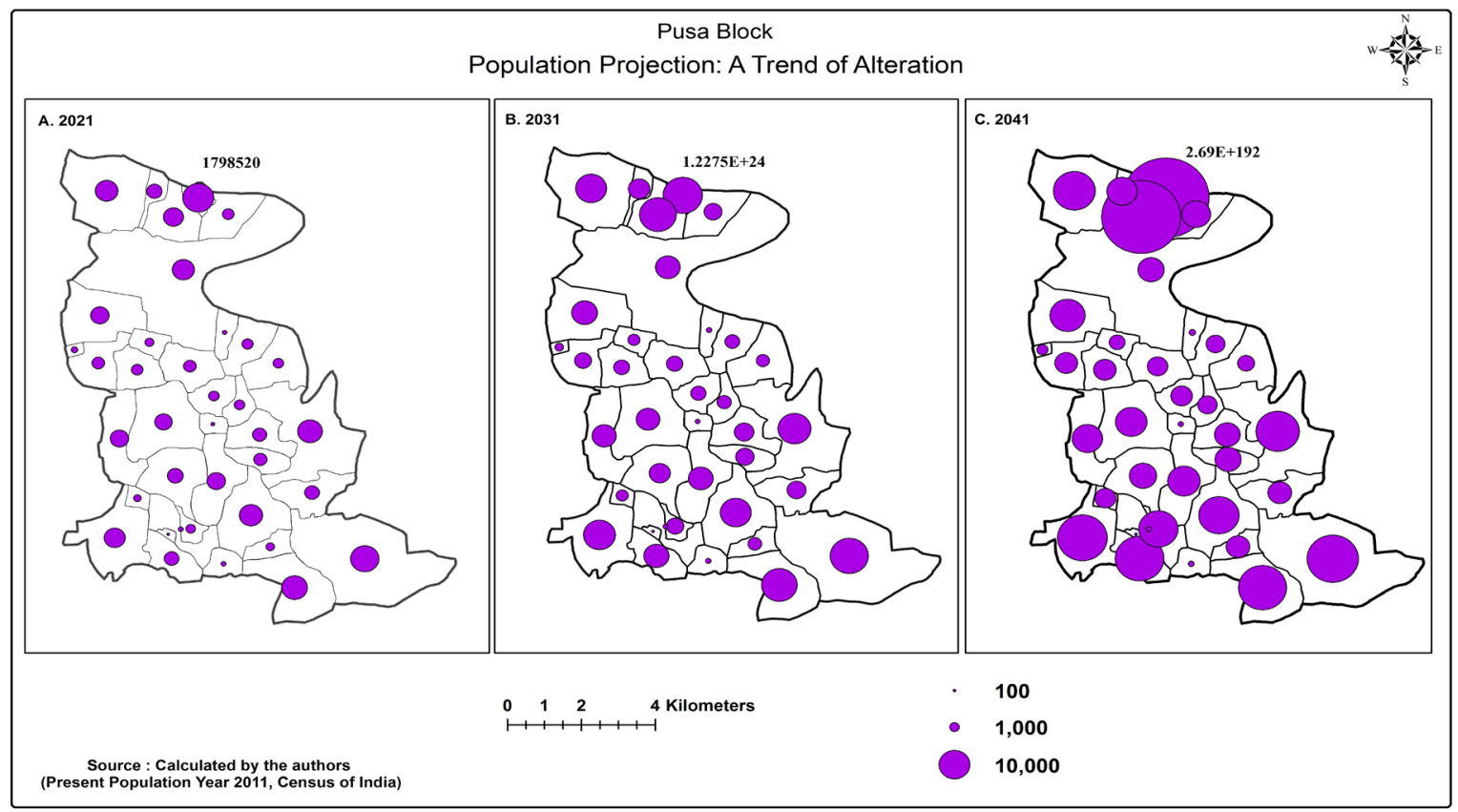

Fig3. Probabilistic future Population Projection for three decades

\section{Spatial Distribution of Population}

Population distribution signifies the splurge of population in an area. Most of the people distributed over the globe live in less developed countries (LDCs)and nearly all of the world population growth is concentrated in LDCs (Clarke, 1972). The analysis of population distribution, thus deals with the way in which they are distributed over an area which either may be sparse; dense or agglomerated distribution etc. There are marked prevalent regional contrasts in the degree of concentration and dispersion of population across the globe.

\section{Population distribution of Pusa Block}

The present study propagates micro-level disparities in population spatially with diminutive discrepancies in inter villages settlement pattern bestowed upon ecological and physical factors. In present study, there is spatial variation in the distribution of population at the micro-level, which exists with little variations in the inter villages settlement patterns on the ecological and physical factors. It is apparent from the (figure 4) that the spatial variation of population distribution in the area is not very uneven, although it is concentrated along the 
Spatio-temporal Analysis of Demographic Characteristics: A Case Study of Samastipur District, India

major roads counting across the emergent service centres like Bairo Patti, Harpur Mohamda and Chakla Waini positioned in central, northern and southern part of the study area. A few villages of north-eastern; northwestern and south-eastern part of the study area cover the sparse distribution of population. It is noteworthy from the table- 4 that the total population of the study area in 2001 and 2011 were distributed among the 37 villages of different size and shapes. The size of the village population is directly proportional to the village area. In 2001, the total population of the study area was 110429 persons out of which 43483 persons (39.38\% of total) are concentrated only in six villages (out of 37 villages) having population size between 5000 to 9999 persons. More than one-fourth of the total population (29.57\%) are focussed in 10 villages having population size between 2000-4999 persons. There were only five villages which had their population size less than 200499 persons, i.e., Pusa Mahamadpur Deopar, Bishunpur Birauli, Bhairo patti, Chak Abdullah, urf Milki and Naraenpur. These five villages cover only 1.69 per cent of the total population. There is only one village (Harpur Pusa) which falls under the category of more than 10,000 persons.

Table 4. Distribution of population on the basis of its size, 2001 and 2011

\begin{tabular}{|c|c|c|c|c|c|c|}
\hline $\begin{array}{c}\text { Population Size } \\
\text { (Persons) }\end{array}$ & \multicolumn{3}{|c|}{ 2001 } & \multicolumn{3}{c|}{2011} \\
\hline & $\begin{array}{c}\text { No. of } \\
\text { Villages }\end{array}$ & $\begin{array}{c}\text { Total } \\
\text { Pop }\end{array}$ & Pop (\%) & $\begin{array}{c}\text { No. of } \\
\text { Villages }\end{array}$ & $\begin{array}{c}\text { Total } \\
\text { Pop }\end{array}$ & Pop (\%) \\
\hline$<200$ & 0 & 0 & 0 & 0 & 0 & 0 \\
\hline $200-499$ & 5 & 1876 & 1.70 & 3 & 919 & 0.69 \\
\hline $500-999$ & 4 & 2267 & 2.05 & 6 & 4307 & 3.24 \\
\hline $1000-1999$ & 11 & 16282 & 14.74 & 6 & 10149 & 7.63 \\
\hline $2000-4999$ & 10 & 32650 & 29.57 & 13 & 42453 & 31.94 \\
\hline $5000-9999$ & 6 & 43483 & 39.38 & 7 & 51781 & 38.95 \\
\hline$>10000$ & 1 & 13871 & 12.56 & 2 & 23323 & 17.55 \\
\hline Total & 37 & 110429 & 100 & 37 & 132932 & 100 \\
\hline
\end{tabular}

Source. Census Data 2001 and 2011.

The year 2011 observed the population dissemination figure fluctuating significantly in view of the population size. Now, there is not even a single village which could fall under the category of below 200 population size. In 2011, the maximum concentration of population (38.95\%) was under the category of 5000-9999 people population size, which was in 2001 under same 5000-9999 (39.38 \%). There are two villages (Harpur Pusa, Chandauli) which falls under the category of more than 10,000 persons. As it is evident from the table (4), all categories of population size have augmented in context to number of villages and their populace during 2001 to 2011. It does seem the decrease in number of villages and their growth rate under population size between 1000-1999 and 200-499 during 2001 to 2011. Therefore, it is clear from the evidences that by the passages of time and an upsurge in the infrastructural facilities the size of the population among the villages tends to increase in many cases (Table 4). 


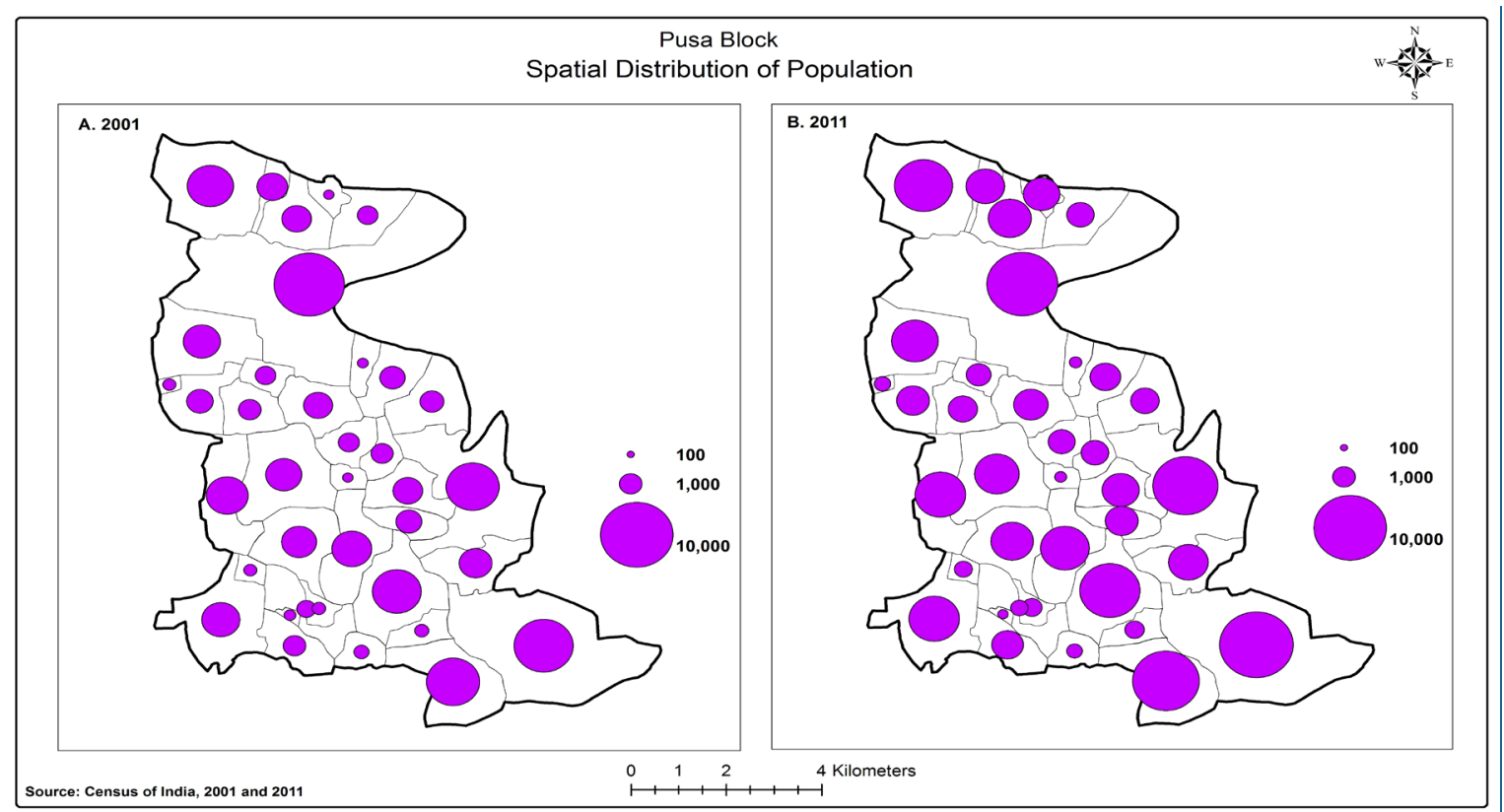

Fig4. Village-wise decadal spatial population variation

\section{Spatial Distribution of Population Density}

Land and people reckoned as the two vital elements, their ratio is taken to be an indispensable consideration in all population studies. Thus, population density is a simple measurement of the number of people in an area. It is an average number which shows the relationship between population size and the land area. Density can be computed in several ways, including arithmetic density, physiological density and agricultural density. These measures of density aid geographers to describe the distribution of people, in contrast to available resources. Geographers most frequently use arithmetic density, which is the total number of people divided by total land area; this measure is also called population density (Rubenstein, 2010, p. 30). An exertion has been made here to elucidate only spatial-temporal variation of arithmetic density (Figure 5) and relationship between proportion of land resource and population density (Table 5).

Table 5. Variation in Population Density, 2001-2011

\begin{tabular}{|l|l|l|l|l|l|l|}
\hline Density (Persons/ha) & Types & \multicolumn{5}{|c|}{ Number of Villages } \\
\hline & & 1991 & 2001 & 2011 & $\begin{array}{l}\text { Variation } \\
(2001-2011)\end{array}$ & \begin{tabular}{l} 
(1991-2011) \\
\hline$>20$
\end{tabular} \\
& Very High & 4 & 5 & 12 & 1 & 2 \\
\hline 16 to 20 & High & 9 & 7 & 11 & 0 & 0 \\
\hline 11 to 15 & Moderate & 12 & 16 & 9 & 1 & 1 \\
\hline 5 to 10 & Low & 12 & 9 & 5 & 8 & 18 \\
\hline$<5$ & Very Low & 0 & 0 & 0 & 27 & 16 \\
\hline
\end{tabular}

Source. Census Data 2001 and 2011. 


\section{Spatio-temporal Analysis of Demographic Characteristics: A Case Study of Samastipur District, India}

Population density in the present paper has been evaluated for the years of 2001 and 2011. Density of the area in 2001 was 16 persons per hectare while, in 2011 it increased to 21 persons per hectare. Although, the overall variation in density accounts only of five persons per hectare, it varies significantly at village level (Figure 4). The area under study has been divided into five categories of arithmetic density for each census year (Table-5). In 2001, the mass proportion of area (16 village) were under the category of moderate population density (11-15 persons/ha) which was 12 villages in previous census year 1991, most of which shifted into the category of high (16 to 20 persons/ha) and very high population density ( $>20$ persons/ha) in 2011. The table (5) shows that, there is a positive move of twelve villages into the category of high population density whereas, it is negative in case of moderate and low population density. Therefore, it is clear from the table (5) that the concentration of population per unit area (persons/ha) has increased over the decades.

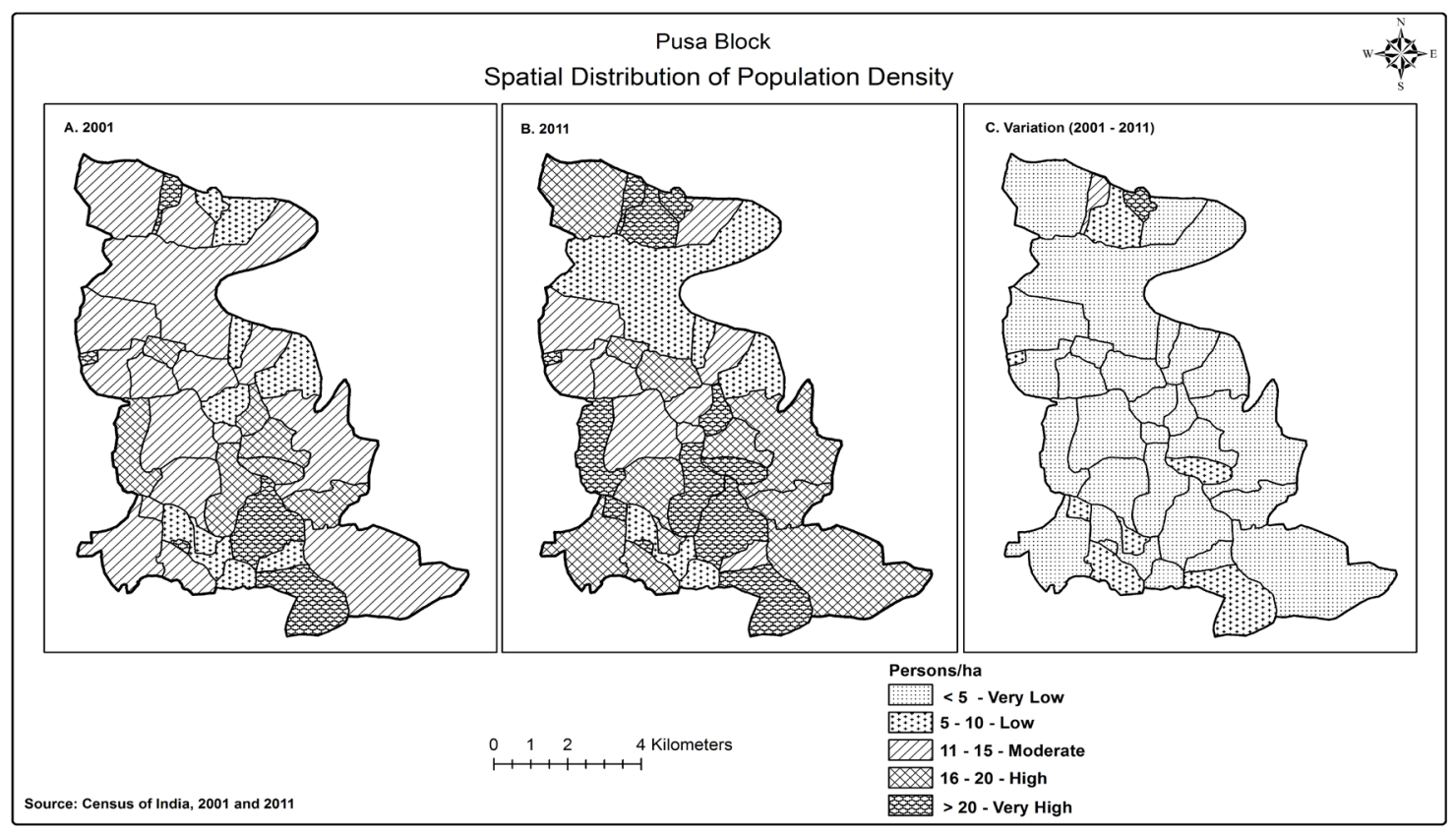

Fig5. Spatial distribution of population density in Pusa block

Table6: Relationship between proportion of land resource and population density, 2011

\begin{tabular}{|c|c|c|c|}
\hline $\begin{array}{c}\text { Five Villages by Area } \\
\text { (ha) }\end{array}$ & $\begin{array}{c}\text { Density } \\
\text { (persons/ha) }\end{array}$ & Five Villages by Area (ha) & Density (persons/ha) \\
\hline $\begin{array}{c}\text { MahamadpurKuori } \\
(302.7)\end{array}$ & 5 & $\begin{array}{c}\text { MadapurChhapra } \\
\text { (57.46) }\end{array}$ & 80 \\
\hline $\begin{array}{c}\text { BishunpurBirauli } \\
(47.75)\end{array}$ & 8 & $\begin{array}{c}\text { PusaMahamadpur } \\
\text { Deopar(37.64) }\end{array}$ & 59 \\
\hline $\begin{array}{c}\text { MadhopurKhairi } \\
(55.04)\end{array}$ & 8 & $\begin{array}{c}\text { Malikorh } \\
(167.94)\end{array}$ & 33 \\
\hline $\begin{array}{c}\text { MahamadpurBirauli } \\
(147.71)\end{array}$ & 9 & $\begin{array}{c}\text { Chandauli } \\
(763.23)\end{array}$ & 26 \\
\hline $\begin{array}{c}\text { Khobgawan } \\
(326.98)\end{array}$ & 10 & $\begin{array}{c}\text { Kubauli Ram } \\
(319.7)\end{array}$ & \\
\hline
\end{tabular}

Source. Census Data 2011.

Note: Figures in parentheses show the area of villages. 
The association of the size of villages in terms of their area and population density does not reveal an affirmative correlation in all the cases (Table-6). It well reflects from the table-6 that the villages having high land sharing, shares less density in comparison with low land sharing villages. Madapur Chhapra which has registered among lowest land proportion (57.46 ha) account the highest density of population (80 persons/ha) in 2011 while, Mahamadpur Kuori which has registered among highest land resource (302.7 ha) account one of the lowest density of population (5 persons/ha) in 2011.

\section{CONCLUSION}

Allied with physical, ecological and socio-economic dynamics the present study divulges coarse spatial variation of growth, distribution and density of population within Pusa block. The area is categorised on the verse of high population growth rate during 1991-2011. Such growth rate is more prominent in case of total population and SC population than that of the infant population (0-6 year's age). The study also divulges that during 19912011 male population grew more rapidly than their female counterpart in case of both the total population and SC population, however this figure is quite startling in case of infant (0-6 age) population where a progress in female population dominates over that of the male population.

The population distribution and density are also fluctuating across the area. Few of the north-eastern; northwestern and south-eastern part of the area are characterized by a meagre population distribution and low density while, the central part of the region succeeding the area of and around service centres are characterized by high density and compact distribution. The maximum concentration of population in 2011 was in the villages having population size of 5000-9999 persons. The number of villages with high growth rate having a population magnitude between 5000-9999 noted significant increases during 1991-2011 which in addition demonstrates that the population increasing and, therefore, it disturbs the spatial distribution as well as the density of population in that area.

Population growth hardly appears as an encouraging prospect while projections of future resource necessities and environmental stress at the grassroots level are perturbing even alarming. It is not easy to envisage the future magnitude of environmental problems in the study area, but significant measures can be taken to incorporate environmental concerns into agricultural development, technology implementation, industrial growth, and resource management. Involving the local communities in the planning and management of such resources is of prominent importance which can trigger sustainable conservation and development at the grassroots level, otherwise, the situation of population high growth is likely to worsen in the future.

\section{REFERENCES}

Adewole and A. Olarewaju, 2012. Effect of population on economic development in Nigeria: A quantitative assessment. IJPS5, 2(5): 1-14, ISSN: 2249-5894.

Barclay, G. W., 1958, Techniques of Population Analysis, New York: John Wiley \& Sons, Inc.

Boadu, E.A., 0000. Rapid Population Growth and Development in Ghana. Population Impact Project.

Bogue, D. J., 1969, Principles of Demography, New York: John Wiley \& Sons, Inc., p. 32.

Census of India, 1991; 2001 and 2011, Primary Census Abstract:: Directorate of Census Operations'

Chip, S.S., 1995, Demographic Dynamics in the Trans Himalayan Tribal Region of Kinnaur H.P: Perspective on Socio Economic Implications, Geographical Review of India, Vol. 57, NO. 1, PP. 20-28.

Clarke, J.I., 1965, Population Geography, Oxford: Pergamon Press. 
Spatio-temporal Analysis of Demographic Characteristics: A Case Study of Samastipur District, India

Clarke, J.I., 1972, ed., The Less Developed Realm: A Geography of its population, New York: John Wiley \& Sons.

Lee, R., 2011, The outlook for population growth. Science, 333(6042), 569-573.

Population Reference Bureau (2017), 2017 World Population Data Sheet, http://www. prb.org/ pdf17/2017_World_Population.pdf, accessed Jan. 21, 2017.

Rubenstein, J.M., 2010, Contempory Human Geography, New Delhi: PHI Learning Private ltd. PP.28-32.

Sauvy, A., 1969, General Theory of Population, London: Weidenfeld \& Nicolson.

Sharma, J.P., 2012, Poverty and Development in Rural India: A Study of Indian Villages, USA: LAP LAMBERT.

Sharma, P.R., 1978, Spatio-Temporal Pattern of Population Growth and Distribution: A Regional Analysis. The Deccan Geographer, Vol. XVI, No. 1, p.372.

Simon, J. L. 1977, The Economics of Population Growth. Princeton University Press: Princeton New Jersey

Tiwari, P.K., 2011, Population Change and Socio- Economic Development: An Empirical Study, Germany: LAP LAMBERT

Citation: Akhilesh Kumar Mishra, Prabuddh Kumar Mishra. "Spatio-temporal Analysis of Demographic Characteristics: A Case Study of Samastipur District, India. " American Research Journal Of Humanities and Social Sciences, vol 4, no. 1, 2018, pp. 1-14.

Copyright (c) 2018 Akhilesh Kumar Mishra, Prabuddh Kumar Mishra. This is an open access article distributed under the Creative Commons Attribution License, which permits unrestricted use, distribution, and reproduction in any medium, provided the original work is properly cited. 